\title{
KEBIJAKAN KEPALA MADRASAH DALAM MENINGKATKAN KUALITAS PENDIDIKAN DI MADRASAH SENDANGSARI PAJANGAN BANTUL
}

\author{
Muhamad Farizal' ${ }^{1}$, Dwi Yulianto 2 , T. Nurullah ${ }^{3}$, Istiningsih ${ }^{4}$ \\ UIN Sunan Kalijaga Yogyakarta \\ e-mail:119204080048@student.uin-suka.ac.id,219204080051@student.uin-suka.ac.id
}

Diterima: 2 April 2021 I Direvisi: 25 April 2021 I Disetujui: 21 Mei 2021 (C) 2021

Pendidikan Guru Madrasah Ibtidaiyah Fakultas Agama Islam Universitas Islam Malang

\begin{abstract}
Abstrak
Kebijakan yang dibuat seorang pemimpin dalam lembaga pendidikan adalah faktor terpenting demi tercapainya tujuan pendidikan. Penelitian ini bertujuan untuk mengeksplorasi tentang bagaimana kepala madrasah meningkatkan kualitas pendidikan khususnya di Madrasah Sendangsari Bantul. Dengan tujuan penelitian adalah dari aspek (1) kebijakan kepala madrasah dalam meningkatkan kualitas pendidikan di Madrasah Sendangsari, (2) pelaksanaan kebijakan kepala madrasah dalam meningkatkan kualitas pendidikan, (3) implementasi kebijakan kepala madrasah dalam meningkatkan kualitas pendidikan di Madrasah Sendangsari Bantul. Pendekatan penelitian yang digunakan adalah kualitatif deskriptif. Metode pengumpulan data dilakukan dengan cara observasi, wawancara dan dokumentasi. Berdasarkan data yang diperoleh, peneliti menemukan beberapa temuan bahwa kepala madrasah memiliki peran penting didalam meningkatkan kualitas pendidikan pada lembaga yang dipimpin. Seperti pada kebijakan tentang penerapan kedisiplinan terhadap siswa maupun guru, memberikan pelayanan kepada seluruh siswa dan seluruh jajaran lembaga, menjalin komunikasi yang baik kepada seluruh jajaran dilembaga pendidikan, serta menerapkan sifat tanggung jawab dan tenggang rasa.
\end{abstract}

Kata kunci: kepemimpinan, kebijakan kepala madrasah, kualitas pendidikan

\section{Abstract}

The policies made by a leader in an educational institution are the most important factors for achieving educational goals. In this study aims to describe how the implementation of madrasah head daman improve the quality of education in Madrasah Sendangsari Bantul. With the details that the purpose of this research is: (1) The policy of the head of madrasah in improving the quality of education in Madrasah Sendangsari, (2) Implementation of the policy of the head of madrasah in improving the quality of education, (3) Implementation of the policy of the head of madrasah in improving the quality of education in Madrasah Sendangsari Bantul. The research method used is qualitative with descriptive analysis approach. Data collection method is done by observation, interview and documentation. Based on the data obtained, researchers found several findings that madrasah heads have an important role in improving the quality of education in led institutions. As in the policy on the application of discipline to students and teachers, providing services to all students and all levels of institutions, establishing good communication to all levels of educational institutions, applying the nature of responsibility and tolerance.

Key words: leadership, policy, quality of education 


\section{PENDAHULUAN}

Pendidikan merupakan hal penting dalam hidup yang dapat menentukan nasib seseorang di masa depan. Selain untuk mewujudkan kepentingan manusia itu sendiri, pentingnya pendidikan juga memegang peranan penting dalam mewujudkan rencana pemerintah untuk mencerdaskan kehidupan bangsa dan negara yang tertuang dalam tujuan pendidikan nasional. Melalui kualitas pendidikan yang baik dapat meningkatkan kondisi kehidupan sehari-hari masyarakat. Dengan memberikan pendidikan yang diperoleh di madrasah, masyarakat akan mampu mengembangkan dan meningkatkan kualitas hidupnya. Selain itu masyarakat akan mampu berkembang dan maju serta mampu bersaing di era yang semakin berkembang ini. Sebagai suatu sistem, pendidikan yang ada harus dikelola dengan tepat secara efektif serta efisien guna tercapainya tujuan pendidikan nasional. Dalam pengelolaan pendidkan itu sendiri dibutuhkan manajer dengan kinerja terbaik untuk mencapai tujuannya yaitu memberikan lulusan terbaik yang diharapkan oleh masyarakat.

Tujuan pendidikan nasional juga tertuang didalam Standar Nasional Pendidikan pada PP No. 19 tahun 2005 yang berisi 8 standarisasi yang wajib dilaksanakan pada pendidkan nasional, yaitu: (1) standar isi, (2) standar proses, (3) standar kompetensi lulusan, (4) standar pendidik dan tenaga pendidikan, (5) standar sarana dan prasarana, (6) standar pengelolaan, (7) standar pembiayaan dan (8) standar penilaian pendidikan. Diantara kedelapan standar tersebut, salah satu hal terpenting yang terkait dengan kualitas lulusan yang ditunjukkan dengan kemampuan lulusan adalah tingkat pendidk dan tenaga pendidik. Artinya demi tercapainya kwalitas lulusan yang diinginkan maka kualitas tenagaa pengajar (dalam hal ini guru dan pendidik dalam hal ini kepala madrasah dan madrasah) perlu ditingkatkan dan dioptimalkan termasuk pengawas, eksperimen. Asisten ruangan, pustakawan, staf administrasi dan personel lainnya.

Fakta di lapangan pendidikan di Indonesia masih menghadapi permasalahan utama, di antaranya kualitas dan hasil pendidikan yang dinilai rendah dan sia-sia. Mulyasa (2013: 37) mengatakan hal yang sama bahwa munculnya lulusan pendidikan masih menjadi beban negara, yaitu banyak lulusan pendidikan yang tidak memiliki kesempatan kerja karena pendidikan tidak ada hubungannya dengan kebutuhan sosial. Dalam rangka memajukan dan meningkatkan pendidikan perlu dilakukan beberapa langkah supaya bisa berperan aktif pada kwalitas SDM pendidk dan tenaga pendidik yaitu kepala madrasah/madrasah. Peran pemimpin dalam pendidikan memberikan kesan yang menarik dan 
diharapkan dapat mendorong perkembangan institusi. Berhasil tidaknya suatu lembaga atau organisasi tergantung pada kebijakan pimpinannya.

Kepemimpinan itu sendiri adalah kemampuan untuk membimbing, memobilisasi dan mempengaruhi sekelompok orang guna tercapainya tujuan dalam kondisi tertentu. Pemimpin juga menjadi salah satu bagian manajemen suatu organisasi dan merupakan posisi inti. Dengan kata lain, kepemimpinan pemimpin memiliki peran sebagai koordinator dalam proses kerjasama antar orang dalam organisasi. Sebagai penanggungjawab lembaga pendidkan, kepala madrasah berfungsi menbangun lingkungan pengajaran yang baik guna mencapai tujuan pendidikan yang diharapkan dapat dicapai oleh lembaga, guru dan siswa itu sendiri. Dalam menjalankan tugas tersebut, kepala madrasah tentunya harus merumuskan kebijakan terkait pendidikan dan memimpin lembaga pendidikan untuk mencapai tujuannya.

Selain itu, kepala madrasah mempunyai tanggung jawab sepenuhnya pada penyelenggaraan manajemen madrasah agar tercipta situasi pembelajaran yang baik di masa depan dan mengawasi guru supaya bisa menjalankan tugasnya yaitu mengajar kepada siswa secara baik. Menurut (Supardi, 2014: 37) Kepala madrasah melaksanakan supervisii dengan tujuan guna menambah kwalitas, proses serta hasil belajar. Kualitas proses belajar mengacu pada kualitas kegiatan belajar yang dilaksanakan oleh guru serta kualitas kegiatan belajar yang dilakukan oleh siswa. Kualitas hasil belajar merupakan kualitas kegiatan pembelajaran yang dilaksanakan oleh guru dan siswa.

Hasil observasi yang dilakukan peneliti dalam penelitian di Madrasah Sendang Sari Bantul bahwa yang mana sebagai lembaga pendidikan yang bertaraf Islami dengan kepemimpinan yang dijalankan oleh Bapak Sarju Riyanto dapat dikatakan sebagai lembaga pencetak mutu dan kualitas lulusan yang baik serta memiliki prestasi baik akademik dan non akademik. Semua kebijakan-kebijakan yang diterapkan oleh Bapak Sarju Riyanto menunjukkan bahwa beliau menjalankan tanggung jawabnya sebagai pemimpin. Hal tersebut sejalan dengan penelitian yang dilakukan oleh Baharuddin, dkk dengan penelitian "Kebijakan Kepala Madrasah Dalam Meningkatkan Kualitas Peserta Didik Dhuafa" yang menunjukkan bahwa dengan diterapkannya pendidikan peseantre, peserta didik dapat lebih mampu mengembangkan prestasi mereka. Hal terebut lah yang dapat membantu meningkatkan kualitas baik peserta didik maupun segala yang berkaitan dengan pendidikan di lembaga terebut (Baharuddin, 2020: 9.)

Oleh karena itu, Penelitian ini bertujuan secara khusus untuk mengetahui bagaimana kebijakan kepemimpinan yang dijalankan oleh kepala madrasah 
supaya dapat menambah kualitas pendidikan dan penyelenggaraan lembaga pendidikan yang dipimpinnya. Dalam hal ini kita dapat melihat peningkatan mutu pendidikan di Madrasah Sendangsari Pajangan Bantul, sehingga peneliti tertarik untuk melakukan penelitian kebijakan yang diambil oleh kepala madrasah untuk meningkatkan mutu pendidikan di madrasah tersebut.

\section{METODE}

Metode penelitian yang digunakan adalah kualitatif dengan pendekatan deskriptif analisis. Penelitian ini merupakan penelitian kualitatif baik secara individu maupun kelompok yang bertujuan sebagai analisis dan deskriptif suatu peristiwa, kejadian, aktifitas sosial, prilaku, keyakinan, pendapat, pemikiran masyarakat (Sukmadinata, 2017: 60). Analisis deskriptif adalah gaya analisis yang tujuannya sebagai penjelas suatu objek berdasarkan penelitian yang dilakukan di lapangan, sehingga hasilnya dapat ditampilkan sebagaimana adanya (Baroroh, 2008: 1).

Pengumpulan data pada penelitian ini dilakukan melalui wawancara. Sumber data dan wawancara dilakukan oleh Sarju Riyanto dari S.Pd selaku Kepala Madrasah Sendangsari, Pajangan, dan Bantul. Tujuan penelitian ini adalah: (1) kebijakan utama peningkatan mutu pendidikan di Madrasah Sendangsari, (2) implementasi kebijakan utama peningkatan mutu pendidikan, dan (3) kebijakan utama penyelenggaraan Madrasah Sendangsari Bantul untuk peningkatan mutu pendidikan.

\section{HASIL DAN PEMBAHASAN}

\section{Kebijakan dan Kualitas Pendidikan}

Dunia pendidikan tidak bisa hidup tanpa kebijakan, kebijakan dapat dirumuskan oleh instansi pemerintah atau madrasah itu sendiri. Kebijakan adalah prinsip yang mengatur semua perilaku untuk memandu tujuan tertentu (Asmoni, 2018: 13). Menurut Rusdiana, (2015: 32) kebijakan diartikan sebagai seperangkat aturan yang dirumuskan oleh pemerintah untuk berupaya membentuk sistem pendidikan yang sesuai dengan tujuan dan cita-cita bersama membangun negara. Selain itu, kebijakan pendidikan dapat diartikan sebagai segala proses serta hasil yang telah dirumuskan pada tahap-tahap terpenting dari pendidikan yang dijabarkan melalui visi dan misi pendidkan guna mencapai tujuan pendidkan masyarakat dalam periode tertentu (Tilaar, 2009: 140). Kebijakan pendidkan mencakup seluruh elemen sistem pendidikan, mulai dari Kementerian Pendidikan, pemerintah kabupaten/kota dan lembaga terkait, serta pendidikan yang 
memerlukan kebijakan penunjang berjenjang. Kebijakan ini mencakup semua bidang operasi pendidikan untuk pengambil keputusan di semua tingkatan. Dimana kebijakan pendidikan mendapat pengaruh dari tren perpolitikan negara, kebiasaan normatif, nilai-nilai serta konsep masadepan negara tersebut (Ali, 2017: 147).

Kebijakan menurut Hough (dalam Harahap, 2019: 11) adalah istilah yang sulit untuk dipahami dan perlu penjelasan lebih lanjut karena biasanya digunakan dengan langkah yang beda serta memperlihatkan berbagai kejadian. Kebijakan pendidikan itu sendiri bisa disusun dan dibagi oleh beberapa kategori sebagai berikut: (1) Kebjakan yang terkait pada fungsi dasar institusi suatu pendidikan, terutama kebijakan yang terkait pada kurkulum, pengesahan tujuan, pendaftaran, serta peneriman siswa, dll. (2) Lembaga individu terkait Kebijakan yang terkait dengan keseluruhan sistem atau bagian pendidikan; (3) Kebijakan yang terkait dengan rekrutmen dan evakuasi, promosi, supervisi dan penggantian seluruh pegawai, dan (4) Kebijakan terkait alokasi sumber daya non-manusia, termasuk keuangan, gedung dan peralatan proses pendidikan.

Kebijakan pendidikan memiliki ciri khas tersendiri menurut Hasbullah (Hasbullah, 2015: 44) Pendidikan adalah warisan kolonial yang khas; (1) Itu adalah elit; (2) Itu berorientasi sosial dan ekonomi; (3) Kebebasan, rasionalitas, berorientasi pada prestasi dan jarak sosial; (4) Tidak berakar pada tradisi dan budaya lokal; ( 4) Terlalu berorientasi pada masyarakat perkotaan. Dari berbagai pemahaman tentang hakikat kebijakan pendidikan, dapat disimpulkan bahwa dalam membangun pendidikan yang memenuhi kondisi nasional atau daerah perlu dirumuskan kebjakan yang pasti sebab apabila kebijakan yang dirumuskan dengan pasti diinginkan dapat memenuhi tujuan pendidikan itu sendiri. Semua pihak, terutama di bawah kepemimpinan kepala pendidikan mengambil keputusan agar dapat mengadopsi semua kebijakan yang ada dengan benar dan sesuai harapan.

Setelah adanya karakteristik kebijakan pendidikan, Hasbullah (2015: 52) menjelaskan terdapat beberapa jenis kebijakan pendidikan, yaitu; (1) Kebijakan substantif, yakni kebijakan mengenai isi, materi, ataupun topik; (2) Kebijakan prosedural, kebijakan mengenai siapa, kelompok serta anggota mana yang berpartisipasi pada perumusan dan pelaksanaan kebijakan; (3) Kebijakan distributif, yakni kebjakan yang kondusif untuk melayani dan memberikan manfaat bagi banyak orang atau sekelompok orang, (4) Kebijakan redistribusi adalah kebijakan yang bertujuan untuk mengalihkan hak, kepemilikan, dan kekayaan masyarakat. Kualitas pendidikan berarti mencapai taraf pendidikan, dengan kata lain pemerataan pendidikan secara adil agar cocok pada standar yang 
sudah ditentukan. Peningkatan mutu pendidkan bertujuan untuk menumbuhkan SDM yang baik serta unggul. Kualita pendidikan sering disebut dengan mutu pendidikan. Sebagaimana tertuang juga pada ketentuan peraturan pemerintah RI No. 19 tahun 2005 mengenai keharusan dalam menjamin kualitas pendidkan disetiap satuan lembaga pendidikan umum maupun non umum. Hal ini dilakukan agar menjalankan seta melewati Standar Nasional Pendidikan. Nurhasan (dalam Harahap, 2019: 37) berpendapat bahwa ada beberapa indikator yang dapat dijadikan standar pada kualitas pendidkan: (1) prestasi pendidkan, (2) proses pendidkan, (3) raw input dan lingkungan. Berikut strategi peningkatan kualitas pendidikan, antara lain:

a. Menerapkan penjaminan mutu pendidikan di setiap institusi pendidikan.

b. Pemeriksaan mutu melalui sertifikasi untuk mengetahui tingkat kelayakan dan kinerja masing-masing lembaga pendidikan terkait dengan pencapaian standar pencapaian nasional.

c. Pemerataan mutu pendidikan pada seluruh jenjang pendidikan seperti: baik pramadrasah, SD, SMP, SMA dan Universitas.

Melalui strategi ini, setiap institusi pendidikan akan berupaya untuk meningkatkan kualitas pendidikan melalui sertifikasi, sehingga dapat dilihat sejauh mana kelayakan dan kelemahan institusi pendidikan tersebut masih ada (Mohammad Ali, 2009: 339). Upaya untuk menjamin dan meningkatkan mutu pendidikan sulit untuk dipisahkan dari hubungannya dengan manajemen mutu.Untuk memberikan pelayanan yang sesuai, semua fungsi manajemen harus dijalankan maksimal mungkin, bahkan lebih dari SNP yang sebelumnya sudah ditentukan. Akan tetapi harus diketahui bahwa tak seluruh departemen pendidikan serta pihak-pihak yang terkait bisa mengerti serta berjanji untuk menjalankan SNP tersebut. Ada beberapa faktor yang mempengaruhinya: (1) kurikulum; (2) media atau alat pendidikan; (3) proses pengajaran; (4) penggunaan alat atau fasilitas. Dengan demikian, kepala madrasah wajib mempunyai kapabilitas personal yang unggul supaya bisa menjadi suri tauladan atau panutan bagi guru-guru, dosen, serta peserta didik. Kepala madrasah juga wajib mempunyai keterampilan manajemen yang unggul untuk mengatur dan membimbing guru dan staf selama proses pembelajaran.

\section{Kebijakan Kepala Madrasah yang Efektif dalam Penentuan Kebijakan}

Salah satu pimpinan pendidkan setingkat satuan yang membidangi pendidikan adalah kepala madrasah yang harus mempunyai landasan pemimpin yang baik, berdedikasi, dan kuat. Oleh karena itu, kunci keberhasilan kepala madrasah dalam kepemimpinannya antara lain: krusialnya pemimpinan kepala 
madrasah, indeks pemimpinan yang efektif oleh kepala madrasah, 10 kunci keberhasilan pemimpinan kepala madrasah, gaya pemimpinan kepala madrasah yang ideal, kepemimpinan masadepan kepala madrasah, dan madrasah. Keinginan kepala madrasah kepada guru serta adab pemimpinan utama. Bagian-bagian tersebut harus diintegrasikan dan dimiliki oleh setiap kepribadian kepala madrasah agar kepala madrasah dapat secara efektif, efisien, mandiri, efisien dan bertanggung jawab melaksanakan seluruh pengelolaan dan kepemimpinan (Mulyadi, 2010: 17)

Menurut penjelasan diatas, semua kebijakan yang dibuat oleh pemimpin madrasah ialah hasil dari keputusan yang telah dipertimbangkan secara bijak dan musyawarah serta dapat memobilisasi seluruh SDM di madrasah agar bisa dimanfaatkan sebaik-baiknya bagi individu atau kelompok masyarakat untuk berprestasi. Tujuan yang diharapkan. Dan fokus ke masa depan. Madrasah adalah institusi pendidikan formal yang menjalankan kebijakan pendidikan nasional serta kebijakan dinas pendidikan kabupaten/kota yang menjadi kewenangan dan kekuasaan pemimpin madrasag. Pemimpin madrasah berperan penuh atas madrasah yang dipimpinnya dan pelaksanaan aturan kebijakan pendidkan nasional yang dirumuskan pemerintah.

Apabila kepala madrasah mengerti posisi madrasah sebagai lembaga yang kompleks dan khusus, dan dapat memikul tanggungjawab madrasah, serta bisa memainkan peran sebagai kepala madrasah, maka mereka berhasil. Bagi kepala madrasah, tugas dan kewajiban yang yang utama saat memajukan dan meningkatkan mutu madrasah demi tercapainya tujuan yang diharapkan antara lain: sebagai pendidk, smanajer, manajer, administrasi, pengawas, dan pemimpin (Marno, 2007: 61). Dalam meningkatkan kualitas madrasah, kepala madrasah yang diangkat menjadi pejabat profesionall sangat diwajibkan supaya merumuskan, melaksanakan, serta memberikan penilaian kebijakan dalam kepemimpinannya.

Beare dan Boyd (dalam Syafaruddin, 2008: 117) mengusulkan lima jenis kebijakan pendidikan diantaranya (1) Menetapkan tujuan dan target suatu madrasah; (2) mendistribusikan layanan serta sumber daya pendidkan, (3) Tentukan tujuan untuk pemberian layanan pendidkan, (4) tentukan layanan pendidkan yang akan diberikan, (5) Untuk menetapkan nilai kapitalisasi kualitas pendidkan guna mendorong perkembangan perekonomian. Dalam hal ini terdapat 3 tahapan yang meliputi perumusan, proses, dan penilaian, sehingga, kepala madrasah wajib merumuskan, melaksanakan dan mengevaluasi kebijakan pendidikan sebagai pejabat profesional. Proses pembuatan dan perumusan kebijakan pendidikan dibagi menjadi tahapan berikut: (1) Agenda setting, untuk 
memasukkan isu ke dalam program pendidkan, (2) perumusan kebijakan yakni perumusan opsi kebijakan guna menyelesaikan suatu permasalahan, (3) mengambil kebijakan adalah kebijakan yang diambil/digunakan sebagai solusi dalam penyelesaian suatu permasalahan, (4) penerapan kebijakan yaitu kebijakan yang sudah diambil serta sudah dijalankan di bidang pendidikan, (5) evaluasi kebijkan mengacu pada langkah-langkah perumusan kebijkan dalam mencapai tujuan kebijkan pendidkan.

Kebijakan efektif kepala madrasah untuk menambah peluang adalah dengan menggelar konferensi yang efektif terhadap guru dalam keadaan kondusif. Dengan demikian sikap kepala madrasah dapat dicapai dengan menunjukkan metode kepemimpinan yang baik dan benar (seperti persahabatan, keintiman, saling mengingatkan dan sepenuhnya mempertimbangkan personalisasi guru. Perilaku positif kepala madrasah secara keseluruhan dapat mendorong, membimbing dan menginspirasi setiap orang untuk bekerja sama mencapai segala sesuatu yang ingin mereka capai (Mulyasa, 2011, hlm. 117). Kepemimpinan kepala madrasah yang efektif biasanya dihubungkan pada posisi manajer pembelajarn, pemimpin yang menginspirasi, manajer sumberdaya, ahli pengorganisasian, kepala budaya, serta menjad pelindung/penasehat guru (Mulyadi, 2010: 69).

\section{Kebijakan Kepala Madrasah dalam Meningkatkan Kualitas Pendidikan di SD Sendangsari Pajangan Bantul}

Pada dasarnya dalam pelaksanaan kegiatan madrasah yang telah diterapkan di Madrasah Sendangsari Pajangan Bantul sudah mencapai standar peningkatan mutu pendidikan lembaga. Kepala madrasah yaitu Bapak Sarju Riyanto berpedoman pada Permendiknas Nomor 19 Tahun 2007 untuk meningkatkan mutu pendidikan di Madrasah Sendangsari Norma tersebut bertujuan untuk mengatur struktur organisasi madrasah, termasuk sistem pengelolaan administrasi yang digambarkan secara jelas dan transparan. Adapun Kepala Madrasah Sendangsari berpedoman pada kriteria pemenuhan standar pengelolaan satuan pendidikan dasar sebagai berikut.

\begin{tabular}{|c|c|c|}
\hline Indikator & Deskripsi Pemenuhan & Bukti Fisik \\
\hline \multirow[t]{2}{*}{$\begin{array}{l}\text { Visi, misi, tujuan } \\
\text { madrasah sesuai } \\
\text { dengan } \\
\text { EDS }\end{array}$} & $\begin{array}{l}\text { Visi, misi dan tujuan madrasah } \\
\text { berpedoman pada kebutuhan } \\
\text { internal dan eksternal SKL dan } \\
\text { madrasah }\end{array}$ & $\begin{array}{l}\text { Laporan EDS } \\
\text { Profil madrasah } \\
\text { Hasil UN dan US }\end{array}$ \\
\hline & $\begin{array}{l}\text { Mengkaji dan merumuskan } \\
\text { kembali visi dan misi Islam secara } \\
\text { rutin }\end{array}$ & $\begin{array}{l}\text { Laporan aktifitas review } \\
\text { rencana strategi }\end{array}$ \\
\hline $\begin{array}{l}\text { Visi, misi, tujuan } \\
\text { madrasah dipahami } \\
\text { oleh semua warga }\end{array}$ & $\begin{array}{l}\text { Sosialisasi visi, misi dan tujuan } \\
\text { madrasah dilakukan kepada } \\
\text { semua warga madrasah }\end{array}$ & $\begin{array}{l}\text { Notula Rapat } \\
\text { Renstra } \\
\text { RKS }\end{array}$ \\
\hline
\end{tabular}




\begin{tabular}{|c|c|c|}
\hline \multirow[t]{2}{*}{ madrasah } & & Spanduk, leaflet, brosur \\
\hline & $\begin{array}{l}\text { Madrasah memiliki visi dan misi, } \\
\text { dan semua komponen Madrasah } \\
\text { dapat dipahami }\end{array}$ & $\begin{array}{l}\text { Rencana strategi } \\
\text { Notulen diskusi } \\
\text { Daftar hadir }\end{array}$ \\
\hline $\begin{array}{l}\text { Rencana kerja } \\
\text { madrasah sesuai } \\
\text { dengan EDS }\end{array}$ & $\begin{array}{l}\text { Penyusunan RKS memperhatikan } \\
\text { pertimbangan komite madrasah } \\
\text { dan disahkan oleh dinas } \\
\text { pendidikan Kabupaten oleh } \\
\text { panitia madrasah bagi madrasah } \\
\text { swasta } \\
\text { Penyusunan rencana peningkatan } \\
\text { mutu pesantren didasarkan pada } \\
\text { hasil asesmen diri, hasil sertifikasi } \\
\text { madrasah dan kelulusan siswa }\end{array}$ & $\begin{array}{l}\text { Hasil EDS } \\
\text { Notula rapat } \\
\text { Daftar hadir kegiatan } \\
\text { Laporan EDS } \\
\text { Hasil UN/US } \\
\text { Hasil akreditasi }\end{array}$ \\
\hline $\begin{array}{l}\text { program kerja } \\
\text { madrasah berorientasi } \\
\text { mutu }\end{array}$ & $\begin{array}{l}\text { Rencana kerja madrasah } \\
\text { mendukung perkembangan } \\
\text { profesionalitas guru }\end{array}$ & $\begin{array}{l}\text { SK penugasan guru } \\
\text { Daftar aktifitas ukuran kualitas } \\
\text { guru }\end{array}$ \\
\hline $\begin{array}{l}\text { Program madrasah } \\
\text { terkait peningkatan } \\
\text { mutu PBM }\end{array}$ & $\begin{array}{l}\text { Madrasah memiliki data rencana } \\
\text { yang bermutu, meliputi } \\
\text { peningkatan PBM, para pendidik } \\
\text { dan sarpras selalu berjalan }\end{array}$ & $\begin{array}{l}\text { RKT } \\
\text { RKS }\end{array}$ \\
\hline \multirow[t]{2}{*}{$\begin{array}{l}\text { Kondisi organisasi } \\
\text { mendukung program } \\
\text { madrasah. }\end{array}$} & $\begin{array}{l}\text { Seluruh guru dan komponen } \\
\text { madrasah dilibatkan dalam } \\
\text { pelaksanaan rencana yang } \\
\text { termasuk dalam rencana }\end{array}$ & Laporan kegiatan \\
\hline & $\begin{array}{l}\text { madrasahbekerja sama dengan } \\
\text { lembaga lain untuk mendukung } \\
\text { pelaksanaan rencana kerja } \\
\text { pesantren }\end{array}$ & $\begin{array}{l}\text { MOU } \\
\text { Laporan aktivitas kerja sama }\end{array}$ \\
\hline $\begin{array}{l}\text { Pimpinan melakukan } \\
\text { supervisi dan menilai } \\
\text { berdasarkan standar }\end{array}$ & $\begin{array}{l}\text { Rencana monitoring dan evaluasi } \\
\text { meliputi: monitoring, evaluasi dan } \\
\text { tindak lanjut } \\
\text { Kepala madrasah melakukan } \\
\text { evaluasi pemanfaatan pendidikan } \\
\text { di setiap semester }\end{array}$ & $\begin{array}{l}\text { Dokumen perencanaan dan } \\
\text { laporan rencana pemantauan } \\
\text { Tinjau kehadiran guru } \\
\text { Tinjau kehadiran siswa } \\
\text { Laporan Pengawasan Akademik } \\
\text { Rencana tindak lanjut } \\
\text { Laporan pengawasan akademik }\end{array}$ \\
\hline $\begin{array}{l}\text { Implementasi program } \\
\text { madrasah / madrasah } \\
\text { yang berorientasi pada } \\
\text { kualitas }\end{array}$ & $\begin{array}{l}\text { Madrasah melaksanakan rencana } \\
\text { peningkatan kualitas madrasah. }\end{array}$ & $\begin{array}{l}\text { RKT } \\
\text { Rencana tahunan }\end{array}$ \\
\hline $\begin{array}{l}\text { Madrasah memiliki } \\
\text { POB }\end{array}$ & $\begin{array}{l}\text { Madrasah menyusun pedoman } \\
\text { pengelolaan madrasah } \\
\text { Seluruh pimpinan, pendidik } \\
\text { tenaga kependidikan memiliki } \\
\text { deskripsi penugasan, kewenangan } \\
\text { serta penanggung jawab serta } \\
\text { administrasi madrasah }\end{array}$ & $\begin{array}{l}\text { SK Kepala Madrasah } \\
\text { SOTK } \\
\text { SK penugasan PTK } \\
\text { Tata tertib madrasah } \\
\text { Hasil PKG } \\
\text { SK penugasan Guru } \\
\text { Matrik kompetensi }\end{array}$ \\
\hline $\begin{array}{l}\text { Pelaksanaan kegiatan } \\
\text { madrasah mematuhi } \\
\text { tahapan yang sudah di } \\
\text { tentukan }\end{array}$ & $\begin{array}{l}\text { Pelaksanaan kegiatan pesantren } \\
\text { meliputi perencanaan, } \\
\text { pelaksanaan, pemantauan, } \\
\text { evaluasi dan pelaporan }\end{array}$ & $\begin{array}{l}\text { RKAS } \\
\text { Notulen rapat } \\
\text { Laporan kegiatan }\end{array}$ \\
\hline
\end{tabular}




\begin{tabular}{lll}
\hline $\begin{array}{l}\text { Kegiatan madrasah } \\
\text { terkait dengan program } \\
\text { visi }\end{array}$ & $\begin{array}{l}\text { Madrasah mewujudkan visi dan } \\
\text { misi kegiatan pembelajaran, } \\
\text { pengelolaan PTK dan pelaksanaan } \\
\text { kegiatan. }\end{array}$ & $\begin{array}{l}\text { Laporan kegiatan PPDB } \\
\text { Daftar nama siswa yang } \\
\text { diterima }\end{array}$ \\
\hline $\begin{array}{l}\text { Kondisi madrasah } \\
\text { mensupport } \\
\text { pembelajaran }\end{array}$ & $\begin{array}{l}\text { Budaya dan lingkungan Muslim } \\
\text { kondusif untuk pembelajaran }\end{array}$ & $\begin{array}{l}\text { Tata tertib madrasah } \\
\text { Rencana program pendidikan } \\
\text { manajemen madrasah }\end{array}$ \\
$\begin{array}{l}\text { kepala madrasah melakukan } \\
\text { efektiv dan efisien }\end{array}$ & $\begin{array}{l}\text { Kepanan } \\
\text { manajemen madrasah sercara } \\
\text { evektiv dan efisien guna } \\
\text { meningkatkan kualitas madrasah }\end{array}$ & $\begin{array}{l}\text { Laporan monitoring dan } \\
\text { penilaian }\end{array}$ \\
\hline $\begin{array}{l}\text { Kepala madrasah } \\
\text { menjadi panutan }\end{array}$ & $\begin{array}{l}\text { Kepala madrasah bisa menjadi } \\
\text { panutan untuk seluruh warga } \\
\text { madrasah }\end{array}$ & $\begin{array}{l}\text { Wawancara bersama pendidik } \\
\text { dan peserta didik }\end{array}$ \\
\hline $\begin{array}{l}\text { Manajemen } \\
\text { keadministrasian yang } \\
\text { transparan serta an } \\
\text { akuntabel }\end{array}$ & $\begin{array}{l}\text { Penghuni madrasah bisa } \\
\text { mengakses laporan pengelolaan } \\
\text { keuangan madrasah secara } \\
\text { transparan dan bertanggung } \\
\text { jawab }\end{array}$ & Website madrasah \\
& Laporan keuangan \\
\hline
\end{tabular}

Tabel 1. Kriteria Pemenuhan Standar Pengelolaan Satuan Pendidikan Dasar

Berdasarkan uraian mengenai standar kebijakan pendidikan di atas, maka kebjakan pendidkan adalah seperangkat peraturan yang merupakan wujud yang diutamakan pemerntah saat memajukan dan mendirikan struktur pendidkan yang mempunyai kesamaan pada cita-cita dan tujuannya. Kebjakan pendidkan itu sendiri adalah langkah atau prosedur yang dilaksanakan serta dihasilkan dengan merumuskan tahap-tahap strategis pendidkan, langkah-langkah strategis pendidikan tersebut dituangkan melalui visi, misi pendidkan, dengan tujuan guna mencapai tujuan pendidkan masyarkat. Oleh karena itu, dalam hal ini memang perlu diperhatikan peran kepala madrasah dalam memajukan dan merumuskan kebijakan untuk mencapai tujuan kelembagaan.

Peran pimpinan madrasah dalam merumuskan kebijakan yang bertujuan untuk meningkatkan mutu pendidikan Madrasah Sendangsari sama dengan rencana di awal, setiap hari, setiap minggu, setiap bulan, semester dan akhir tahun ajaran. Selain dari program kepala madrasah yang sudah dibuat, peneliti juga memperoleh hasil dari wawancara pada Kepala Madrasah yaitu Bapak Sarju mengenai kebijakannya di Madrasah yang wawancara dilakukan pada hari Senin, 14 Desember 2020 pukul 09.15 WIB.

"Kebijakan yang saya buat pada Madrasah ini guna memajukan kualitas pendidikan diantaranya; memperhatikan kepatuhan pendidik dan peserta didik, baik dari aspek hadir, penyelesaian tugasnya, mematuhi peraturan madrasah dan menjaga kebersihan lingkungan". Kemudian terkait peningkatan prestasi siswa di 
Madrasah Sendangsari, kepala madrasah mengajukan rencana dukungan yaitu rencana formal dan rencana informal. Program informal termasuk kegiatan ekstrakurikuler; Pramuka, Dokter Kecil, Sepak Bola, Tacromen dan Seni Gamelan. Tujuannya untuk meningkatkan bakat yang sebelumnya tidak diketahui siswa. Sebagaimana didukung dari hasil wawancara dengan Kepala Madrasah.

"Dalam meningkatkan prestasi siswa dalam bidang non formal saya membuat program kegiatan ekstrakurikuler diantara lain berupa Pramuka, dokter kecil, sepak bola, sepak takrow, dan seni gamelan. Dengan harapan adanya program tersebut siswa dapat mengenali bakat dan kemampuannya. Hasil dari program tersebut siswa mendapat juara 1 pada lomba sepak takrow antar madrasah se-Kecamatan Pajangan dan masih banyak prestasi lainnya".

Dari hasil wawancara diatas, bisa disimpulkan bahwasanya perencanaan dibuat oleh kepala madrasah dan seluruh warga madrasah menunjukkan pentingnya pengenalan bakat siswa sejak dini. Selain itu, mengenai program formal wawancara yang dilakukan oleh kepala madrasah terhadap kebijakan yang dirumuskannya; melakukan pelatihan guru, membuat peralatan dan media pembelajaran, dan memberikan bimbingan tambahan bagi siswa berupa kelas komputer, serta bimbingan belajar mata pelajaran ujian nasional. Melalui perencanaan ini tujuannya mampu menolong peserta didik dan pendidik pada peningkatan kemampuan dan prestasinya dalam proses pembelajaran. Untuk mengatasi masalah menurunnya prestasi siswa, kepala madrasah hendak mengadakan pertemuan bersama wali siswa pada setiap akhir bulan untuk merumuskan suatu kebijakan atau rencana. Sebagaimana yang diungkapkan oleh Kepala Madrasah sebagai berikut:

"Ya, ketika ada permasalahan mengenai prestasi siswa madrasah ini membuat suatu program pertemuan antar wali murid yang dilakukan setiap akhir bulan. Pertemuan ini kami lakukan dengan harapan tetap terjalin komunikasi bersama pendidik dan orang tua peserta didik mengenai permasalahan-permasalahan pada siswa tersebut selama proses pembelajaran sehingga dapat ditemukan solusi bersama ketika siswa mengalami penurunan prestasi".

Menanggapi pernyataan di atas, kebijakan kepala madrasah dalam menjalankan tugas dan kewajibannya sebagai pemimpin akan selalu membutuhkan pertimbangan dari seorang pendidik, peserta didik, serta orang tua peserta didik. Sehingga, kebijakan ini tentunya sangat membantu para orang tua serta pendidik pada peningkatan prestasi akademik peserta didik dalam proses pembelajaran. Tentunya, pekerjaan yang dilakukan kepala madrasah juga berpedoman pada standar kepemimpinan pendidikan. Berdasarkan wawancara 
serta observasi yang dilakukan oleh peneliti di Madrasah Sendangsari melalui Kepala Madrasah, terlihat bahwa kebijakan yang dirumuskan dan dilaksanakan oleh kepala madrasah guna dalam peningkatan kualitas pendidikn baik formal maupun informal telah mencapai hasil yang memuaskan. Kelulusan siswa Madrasah Sendangsari yang baik membuktikan hal tersebut. Secara umum, setiap lulusan Madrasah Sendangsari bisa melanjutkan pendidikan di SMP favorit di Bantul dan DIY.

\section{SIMPULAN}

Kesimpulan dari hasil penelitian diatas, adalah madrasah telah menerapkan kepatuhan mutu untuk meningkatkan kinerja madrasah, artinya telah tercapai 8 standar nasional pendidikan pada pengelolaan madrasah yakni memenuhi standar isi, memenuhi standar proses, dan memenuhi kemampuan siswa pascasarjana. Persyaratan untuk memenuhi persyaratan guru. Pendidik, perwujudan standar sarpras, perwujudan standar pengelolan, perwujudan standar administrasi serta perwujudan standar evaluasi pendidkan. Evaluasi kualitas yang dilaksanakan madrasah dalam melakukan peningkatan kinerja madrasah sangat baik, tercermin dari aspek-aspek sebagai berikut: pembentukan penilaian formatif serta melibatkan indikator proses, ringkasan penilaian yang melibatkan output, indikator hasil dan dampak, dan rencana yang telah ditetapkan. Proses pemenuhan SNP ditinjau.

\section{DAFTAR RUJUKAN}

Baroroh, Ali. (2008). Trik Trik Analisis Statistik dengan SPSS 15. Jakarta: PT. Elex Media Komputindo.

Asmoni. (2018). Kebijakan Peningkatan Mutu Sekolah SMK. Jakad Media Publishing.

Baharuddin, B. (2020). Kebijakan Kepala Madrasah Dalam Meningkatkan Kualitas Peserta Didik Dhuafa. Al-fikrah: Jurnal Manajemen Pendidikan, 8 (1), 1-10.

Mulyasa, E. (2013). Menjadi Kepala Sekolah Profesional. Bandung: PT Remaja Rosdakarya.

Harahap, W. S. A. (2019). Implementasi Kebijakan Kepala Madrasah Dalam Meningkatkan Mutu Pendidikan Di MTS Madinatussalam Tembung [PhD Thesis]. Universitas Islam Negeri Sumatera Utara.

Hasbullah. (2015). Kebijakan Pendidikan dalam Perspektif Teori, Aplikasi, dan Kondisi Objektif Pendidikan di Indonesia. Jakarta: Rajagrafindo Persada.

Marno. (2007). Islam by management and leadership: tinjauan teoritis dan empiris pengembangan lembaga pendidikan Islam. Jakarta: Lintas Pustaka. 
Muhamad Farizal, Dwi Yulianto, T. Nurullah, Istiningsih

Ali, Mohammad. (2009). Pendidikan untuk Pembangunan Nasional, Menuju Bangsa Indonesia yang Mandiri Dan Berdaya Saing Tinggi. Jakarta :Grasindo.

Ali, Muhammad. (2017). Kebijakan Pendidikan Menengah Dalam Perspektif Governance di Indonesia. Malang: Universitas Brawijaya Press.

Mulyadi. (2010). Kepemimpinan Kepala Sekolah dalam Mengembangkan Budaya Mutu. Malang: UIN Malang Press.

Mulyasa. (2011). Manajemen dan Kepemimpinan Kepala Sekolah. Jakarta: Bumi Aksara.

Rusdiana. (2015). Kebijakan Pendidikan dari Filosofi Ke Implementasi. Bandung: Pustaka Setia.

Sukmadinata, N. S. (2017). Metode Penelitian Pendidikan. Bandung: Remaja Rosdakarya.

Supardi. (2014). Kinerja Guru. Jakarta: Rajagrafindo Persada.

Syafaruddin. (2008). Efektivitas kebijakan pendidikan: konsep, strategi dan aplikasi kebijakan menuju organisasi sekolah efektif. Jakarta: Rineka Cipta.

Tilaar, N. R. (2009). Kebijakan Pendidikan. Jakarta: Pustaka Pelajar. 